\title{
Web based financial disclosure in European context: European transparency directive analysis
}

\author{
DhouhaKhrifech $^{1 *}$, WalidKhoufi ${ }^{2}$, Ahmed Ghorbel ${ }^{3}$ \\ ${ }^{1}$ Doctor in Finance and Accounting, Governance, Finance and Accounting Laboratory, \\ Faculty of Economics and Management, Sfax University, Tunisia \\ ${ }^{2}$ Institute of Business Studies, Sfax University, Tunisia \\ ${ }^{3}$ Faculty of Economics and Management, Sfax University, Tunisia \\ *Corresponding author E-mail:khrifech.dhouha@gmail.com
}

\begin{abstract}
This study aims to explain the relationship between firm specific characteristics and the corporate Web based disclosure level in European Union countries. European companies should apply the transparency directive requirements, which clarifies principal component of corporate Websites content. We analyze the Websites content of 197 listed groups on capital market of six European countries: Germany, Spain, French, Italy, Netherlands and UK.

Web disclosure level, endogenous variable, is measured by disclosure index. It includes four dimensions: content, timeliness, technology and user supports.

Our findings show that profitability, concentration ownership, information technology (IT) sector and Big 4 affect significantly Web disclosure index. We conclude that IT sector determining factor of Web financial disclosure in Europe.
\end{abstract}

Keywords: Corporate Websites; European Directive; Information Disclosure; OLS Rank Transformation Regression; Regulatory Information.

\section{Introduction}

Since 1990's years, listing companies on the world utilize the World Wide Web, as a new tool for the information dissemination. They communicate financial and non-financial information through their corporate Websites to shareholders and they practice the "Internet financial reporting (IFR)".

IFR refers to the announcement of financial reports and statements on the listed companies Web sites. Others financial and nonfinancial information can be diffusing on their sites. We designate the Web based disclosure (WBD) practices, (Prabowo \& Angkoso, (2006))

Basing to the XBRL protocol, information dissemination in a digital format pervade around the Word. Internet "is a unique information disclosure tool that encourages flexible forms of presentation and allows immediate, broad, and inexpensive communication to investors", (Kelton \& Yang, (2008), p 63). Information presentation formats permit alternative to facility accessibility and understand information, which many insure reliability and transparency information and affect investment' decision, (Hodge and al. (2004)).

Scholars were interesting to analyze Websites based reporting. There describe and explicit the financial disclosure through Websites of listed firms in different countries, (Marston \& Polei, (2004)). Explanatory studies examine the IFR determinants in several countries: there are been conducted in developed countries (Craven \& Marston, 1999, Debreceny and al. 2002, Boubaker and al. 2012...) and in emerging countries, (Henchiri, 2011, Puspitaningum \& Atmini, 2012...). There found that firm characteristics are the IFR determining factors.
Previously, financial disclosure at corporate Web is voluntary, unregulated disclosure practice. Any regulatory bodies require the possession of Website and the publication of financial statements at corporate site, (Prentice and al. 1999, Ettredge and al. 2001). At over time, online disclosure receives more attention by accounting bodies and markets regulators.

Some of them were presented a set of recommendations identifying the "best online financial disclosure" by listed firms, such as IASC, (1999), FASB, (2000). Others of financial authorities mandate the use of Websites as information diffusion tool and they order specific information, which should be incorporated on the corporate site (SEC, 2003, COB, 2007).

European Union (EU) was establishing a list of corporate information transparency norms, which reinforce more investors' confidence. 2004/109/CE European directive relating the harmonization of transparency standards requires regulated information publication by trading companies on regulated market. The article 17 of this directive authorizes the use of electronic mean, as a corporate information publication tool, a well site Web.

In this study, we analyze and compare the regulated information disclosure practice between listing companies in European developed countries. We examine the relationship between firm specific characteristics and Web disclosure level on European groups' websites.

This study contributes to IFR existing literature by investigating the difference of the extent of Web based regulated and voluntary information published between different companies.

It realizes by comparing six countries from two different accounting models. There are Anglo-Saxon and Continental models.

This paper is structured as follow: the first section provides the concise overview of the Web reporting' previous literature. The 
second section details the theoretical foundation and hypotheses. The firth section describes the research methodology and the final section discusses empirical results and multiple regression analysis.

\section{Web based disclosure: literature review}

Marston \& Polei, (2004) classified the Web based disclosure studies to two categories: descriptive and exploratory studies.

\subsection{Descriptive studies}

Previous descriptive studies are exploratory, which identified and described Internet based financial reporting practice (IFR) of listed companies. These were interested into the content and format of Internet financial reporting.

Many accounting standard setters published studies, which specifying the nature of Web based business and financial reporting (ISAC, 1999, CICCA, 1999, FASB, 2000).

Accounting researchers were carried again a descriptive studies of IFR practices in individual countries, (Louwers and al., 1996, Petravick \& Gillet 1996, Gray \& Debreceny 1997, Brennan \& Hourigan 1998, Gowthorpe \& Amat 1999...) and others studies compared those practices between two or more countries, (Lymer \& Tallberg 1997, Deller and al. 1999, Allam \& Lymer 2003...).

Recently, Abdalmuttaleb \& Al-Sartawi, (2016) qualified the level of online financial disclosure usage in the Gulf Cooperation Council, (GCC) listed companies. They showed that the majority of the GCC companies disclosed a good level of content and format presentation dimension information through their Web site. They indicate that the content dimension differs from one country to other and from industry type to other and that the level of presentation dimension was better in Oman than in Bahrain and on banking companies than insurance and investment companies.

\subsection{Explanatory studies}

Researchers were experienced an empirical investigation attempt to determine explanatory factors of Web based financial disclosure. They examined the relationship between company and country specific characteristics and Internet based financial disclosure of listed firms. Those studies were realized into a signal country and other concerned the comparison between two or more countries. Table 1 presents some of IFR exploratory studies.

Table 1: IFR Exploratory Studies

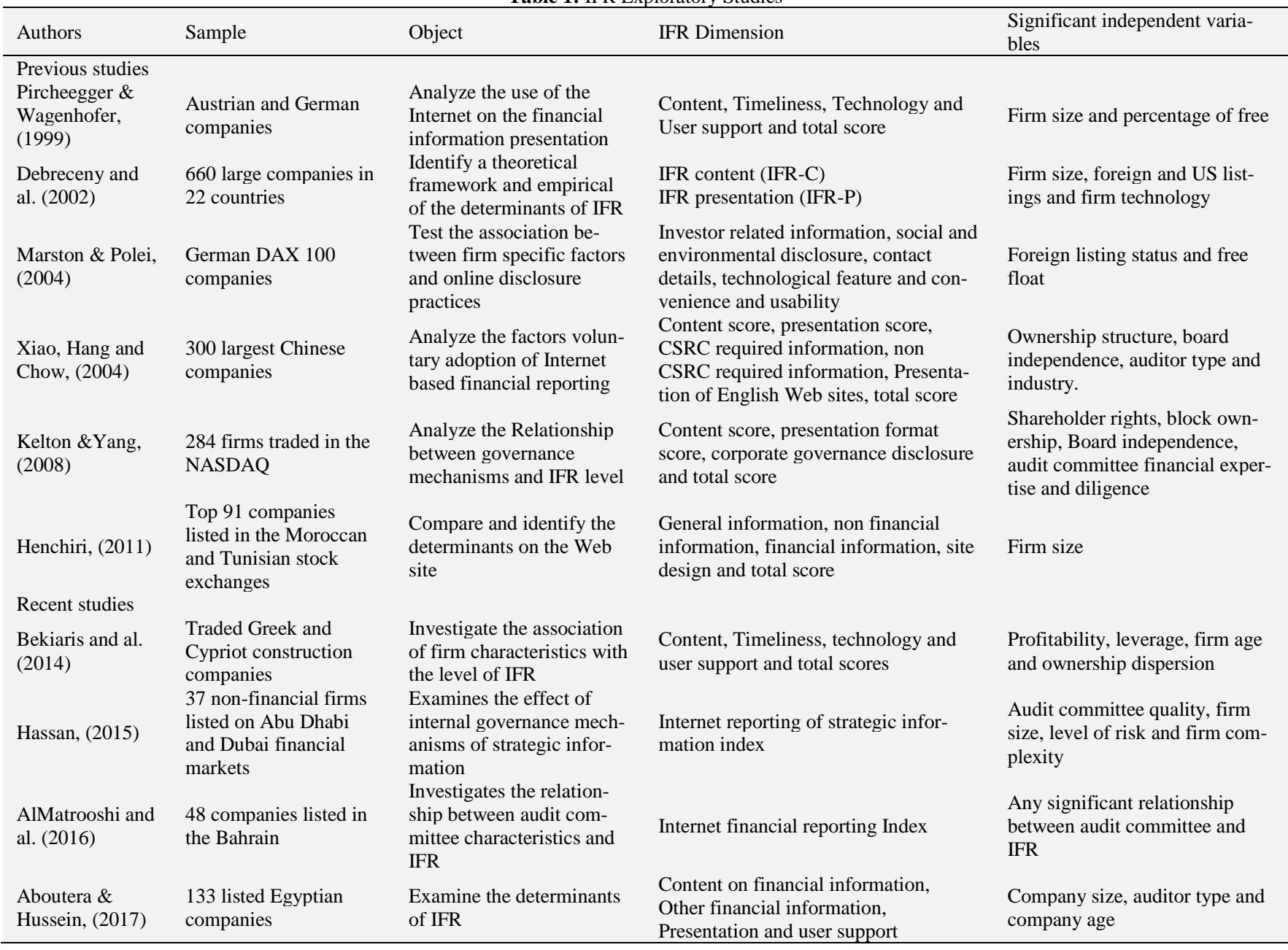

\section{Theoretical background and research hy- potheses}

Researchers indicated that voluntary disclosure theories extended to explain Web based communication managerial motivations, (Debreceny and al. 2002, Xiao and al. 2004). Those theories were considered an IFR theoretical framework, which clarify the rela- tionship between the firm specific characteristics and the level of Web based financial disclosure.

\subsection{Web based disclosure theories}

Agency and signal theories (Xiao and al.2004, Craven \& Marston 1999), proprietary and political costs theories, (Alvarez and al, (2008)) and cost benefit analysis, (Oyelere and al. 2003) constitute the IFR theoretical framework. 
Xiao and al. (2004) and Dolinsek and al. (2014) suggest that innovation diffusion theory can again explain the adoption of Internet financial disclosure.

\subsubsection{Agency theory}

Agency theory concerned the relationship between the principal and the agent, which arising the separation between the ownership and the control of a company. In this case, it result problems of interest conflicts and information asymmetry, (Cotter and al. (2011)).

Both of these parties seek to maximize their utility: managers seek personal interests and shareholders would protect them self against this opportunism behavior. However, managers will disclose more information on the annual report in order reduce agency costs, (Watson and al. (2002)).

The use of Internet, tool of financial communication, can solve agency problems. Investors can access easily and rapidly to financial and accounting information a low cost. This access can decrease asymmetry problems between managers and shareholders and reduce agency costs, (Ashbaugh and al.1999, Debreceny and al.2002).

\subsubsection{Signal theory}

Signal theory suggests that more profitable companies are more likely to communicate information, to signal a good new and distinguish them from other firm less profitable.

Managers are more motivated to disclose more private information to investors in order to reduce the information asymmetry and increase the value of the firm, (Alvarez and al., (2008)).

\subsubsection{Proprietary cost theory}

Proprietary cost theory suggests that the production and communication private information can hurt the competitive position of a firm. Verrecchia, (1983) and Prencipe, (2004) indicated that dissemination information to competitors will be a competitive disadvantage to a firm, generating "Proprietary costs".

\subsubsection{Political cost theory}

Firm can utilize voluntary disclosure, allowing the improvement their relationship with external stakeholders, (governments, suppliers, consumers....), (Watts \& Zimmerman, (1978)). Firms, which high political visibility, will disclose more information in order to achieve social pressures (such as governments), reduce political costs (such as taxes) and obtain some advantages (taxing advantages), (Deegan, (1996)).

\subsubsection{Cost benefit analysis}

Voluntary disclosure decision can benefit firm advantages and support costs, (Gray \& Roberts, 1992, Meek and al.1999). Cooke, (1989) suggests that the benefits must exceed the voluntary disclosure costs.

Against, the use of Internet such as medium of financial publication, favor more advantages to firm, investors and stakeholders, (Turel, (2010)).

Web site facilities the access and the reliability of information: information 'users can interpret information, advising in the decision making process, (Bonson \& Escobar, (2006)).

Consequently, the Web ensures high quality financial information (such as transparency, relevance, reliability...) at a lower cost than paper support

The electronic format of financial reporting allows to supports information disclosure costs (preparation, printing and distribution costs of quarterly and annual reports). But, it creates also news costs, which they are related to the costs of creation, update and the maintenance of Web sites, (Ashbaugh and al. (1999)).

\subsubsection{Innovation diffusion theory}

According to Rogers, (2003), innovation diffusion explains how a new innovations and ideas are accepted gradually and perceived as a useful adoption in a social system and at time sequence, (AlHtaybat and al. (2013)).

In accordance to Rogers, the adoption of the Internet, such as a channel of accounting and financial information, is an innovation facilities and promotes the interpersonal interaction.

Communicating corporate information on the Web allows firm a new attractive and sophistical dialogue with larger number of shareholders and larger public, which strengthen the management decision process, (AbuGhazaleh and al. 2012, Dolinsek and al. 2014).

\subsection{Hypotheses development}

\subsubsection{Firm size}

The relationship between firm size and voluntary disclosure was frequently examined. Chow \& Wong-Boren 1987, Cooke 1989, Botosan 1997, Ahmed \& Courtis 1999, Owusu-Ansah 1998, Depoers 2000 and others found that this relationship is significant and positive.

They indicated that larger companies disclose more information on their annual report, in order to reduce the asymmetry information and agency and political costs, (Alvarez and al. (2008)).

In accordance to an innovation diffusion perspective, firm size is reviewed as a predictor of organizational innovativeness since that it is a surrogate measure of many dimensions such as total resources, personal resources and organizational structure..., (Rogers, (1995)).

Larger firms are more able to follow a new technological development and adopt mass media channel communication, as a mean of communication financial information, (Al-Htaybat and al. (2013).

Previous studies indicated that larger firms, with greater agency and political costs, are more likely to disclose more information on their Web site. They indicated a positive association between firm size and the Internet financial reporting, (Ashbaugh and al. 1999, Debreceny and al. 2002, Marston \& Polei, 2004, Bollen and al. 2006, AbuGhazaleh and al. 2012, Omran \& Ramdhony, $2016 \ldots$... It is hypothesized that:

H1: Firm size affects positively the level of Web based financial information disclosure.

\subsubsection{Profitability}

According to Craven \& Marston, (1999), the use of Internet constitutes as better signal for the firm performance. That also, more profitable companies are more susceptible to create their Web sites and communication their financial and strategic information electronically, distinguishing than the less profitable companies. Managers of profitable companies want to increase the level of financial information on the Web site, in order to attract the confidence of investors and the continuity of firm activity, (Oyelere and al. (2003)).

Empirical studies suggest that firm profitability affect significantly and positively the level of Web based financial disclosure. But, their empirical presents mixed evidences.

Ashbaugh and al. (1999), Ettredge and al. (2002), Oyelere and al. (2003), Marston \& Polei, (2004), Xiao and al. (2004), Bollen and al. (2006) and Andrikopoulos and al. (2007) showed that the profitability is not significantly related to the financial information on line.

Boubaker and al. (2012) confirmed that profitability is significantly and positively associated to the level of Internet financial reporting in French. It is hypothesized that:

$\mathrm{H} 2$ : Profitability affects positively the level of Web based financial information disclosure. 


\subsubsection{Liquidity}

According to signal theory, a high level of firm liquidity constitutes a better signal of financial position: firms will show their ability to meet their current engagements. Also, those firms disclose more information, signaling their performance to shareholders, (Cooke, (1989)).

Previous studies indicated that highly liquid firms are more likely disclose corporate information on their annual report, (Alsaeed, (2005), Aljifri and al. (2014)).

Oyelere and al., (2003) reported that liquidity is significantly and positively related to Internet financial reporting in New Zeeland. This result is indicated by Hossain and al. (2012), Puspitaningrum \& Atmini, (2012). It is hypothesized that:

H3: Firm liquidity affects positively the level of Web based financial information disclosure.

\subsubsection{Leverage}

Jensen \& Meckling, (1976) showed that creditors would exercise more control with managers, wanting to assume firm obligations and protect their interests. Consequently, many interests' conflicts will rise between both parties and firms will support more agency costs, (particularly, monitoring costs).

Companies with a high leverage ratio would disclose more information on the Web and update information in order to resolve monitoring problems and reduce agency costs, (Debreceny and al. (2002), Oyelere and al. (2003)).

Authors supported a positive association between leverage and the level of financial reporting on the Web site. But, their empirical results are inconsistent. Some studies found no significant relationship (Larra'n \& Giner, (2002), Oyelere and al. (2003), Turrent \& Ariza, (2012), Aboutera \& Hussein, (2017)).

Bekiaris and al., (2014) showed that leverage is significantly associated with Internet based financial reporting quality of construction companies listed in Greek and Cypriot stock exchange. It is hypothesized that:

H4: Leverage affects positively the level of Web based financial information disclosure.

\subsubsection{Ownership concentration}

In the diffusion ownership context, the potential of agency problems between shareholders and managers are greater. A situation of asymmetry information between contracting parties, will be generate, (Prencipe, (2004)). Voluntary disclosure is considering as a mean to resolve the divergence of interest and agency problems. Companies, with a diffused ownership, disclose more information on their annual report, which can reduce agency costs, (Paturel and al., (2006)).

Inversely, high concentrated ownership firm discriminate by the dominance of major shareholders, who influence most the equity owners, (Hannifa \& Cooke, (2002)). Firms are appropriate by a less control and less conflict interests. Also, managers will disclose less information on the annual report, (Arcay \& Vazquez, (2005)).

Abdelsalam \& Street, (2007), Turrent \& Ariza, (2012), Momany and al. (2016) found that the relationship between concentrated ownership and Internet financial reporting is significantly and negatively. It is hypothesized that:

H5: Ownership concentration affects negatively the level of Web based financial information disclosure.

\subsubsection{Sector type}

According to innovation diffusion perspective, information technology (IT) companies are more likely to adopt a mass media, as a channel of information communication because they have more expertise on the technological development then others companies, (Xiao and al. (2004)).

They have more human and technical resources, available to adopt innovations such as Internet. They have more susceptible to ap- propriate a Web site, as a financial reporting channel and to disclose more information on line than others companies.

Boubaker and al. (2012) confirmed that information technology (IT) companies listed in the French stock exchange disclose more information on the Web site then companies of others industries. It is hypothesized that:

H6: Information technology (IT) companies disclose more financial information on their Web sites then others companies.

\section{Methodology}

In this section, we detail the methodology procedure with we specify the sample, measurement of variables and regression model.

\subsection{Sample}

The population of this study comprises of listed companies on a regulated market of European countries. Those companies should apply the 2004/109/CE directive requirements, which concern the harmonization of provision of national (European country) law on periodic and ongoing information requirements.

We select six developed European countries, with high market capitalization stock exchanges: Germany, Spain, French, the Netherlands and the United Kingdom, (UK). There are from two different accounting models: Anglo-Saxon and Continental models.

Our initial sample is composed by 271 groups, including into principal market stock index.

Table 2: Sample Composition

\begin{tabular}{lllll}
\hline$N^{\circ}$ & Country & Stock exchange & $\begin{array}{l}\text { Financial } \\
\text { index }\end{array}$ & $\begin{array}{l}\text { Number of } \\
\text { Companies }\end{array}$ \\
\hline 01 & French & $\begin{array}{l}\text { Paris stock exchange } \\
\text { Milan stock ex- } \\
\text { change }\end{array}$ & $\begin{array}{l}\text { CAC 40 } \\
\text { FTSE }\end{array}$ & 40 \\
02 & Italy & MIB & 40 \\
04 & Netherlands & $\begin{array}{l}\text { Frankfurt stock } \\
\text { exchange } \\
\text { Amsterdam stock } \\
\text { exchanges } \\
\text { Madrid stock ex- }\end{array}$ & DAX & 30 \\
05 & Spain & $\begin{array}{l}\text { AEX } \\
\text { change }\end{array}$ & INDICE & 25 \\
06 & UK & $\begin{array}{l}\text { London stock ex- } \\
\text { change }\end{array}$ & FTSE 100 & 101 \\
\multicolumn{7}{l}{ Final sample } & & & 271 \\
\hline
\end{tabular}

This sample was reduced then to financial sector companies as there have specific and different disclosure requirements, (Gul \& Leung 2004, Huafang \& Jianguo 2007).

We eliminated firms did not have a corporate Web site (Ezat \& ElMasry, (2008)) and downloadable site, ((Lybeart, (2002)). Others companies are traded in two and more stock exchange, we consider the quotation on the domicile-country and we excluded again 8 groups, as there haven't a data. The final sample included 197 groups in the 2011-2012 fiscal year. 
Table 3: Final Sample Description

\begin{tabular}{|c|c|c|c|c|c|}
\hline Country & No Financial companies & Web sites inaccessibility & Dual quotation & Lack data & Number of Companies \\
\hline French & 36 & 0 & 03 & 0 & 33 companies \\
\hline Italy & 27 & 01 & 01 & 0 & 25 companies \\
\hline Germany & 25 & 0 & 0 & 0 & 25 companies \\
\hline Netherlands & 22 & 0 & 03 & 0 & 19 companies \\
\hline Spain & 27 & 0 & 03 & 0 & 24 companies \\
\hline UK & 84 & 02 & 03 & 08 & 71 companies \\
\hline Total & 221 & 03 & 13 & 08 & 197 companies \\
\hline
\end{tabular}

\subsection{Endogenous variable: Web based disclosure}

Previous studies were developed a disclosure scores, as a proxy measuring the quality (Lang \& Lundholm, (1993)) and the quantity of financial information on the annual reports, (Cooke, (1989), Botosan, (1997)). Authors were employed two scoring approach: unweighted and weighted methods.

Researchers claimed that weighted scores are more subjective, which focus on a particular user group, (Cooke, (1989)) and they prefer to employ unweighted method. They considered that unweighted, dichotomous scoring reduces the subjectivity and accords equal important to an each disclosure item, (Gray and al., (1992), Hossain and al., (1995)).

The applicability of scoring approach is a dichotomous: one is assigned if the item is disclosed by each company and zero otherwise presents a problem. Company may be penalized if an item was not relevant. However, Cooke, (1989) proposed the adjustment of non applicable items and the use of index disclosure, which check pertinent items to the business of a company.

Basic on this literature, authors were developed an index, measuring the extent of financial information disclosed on the Web sites of listed firms.

The first attempt of development of IFR index was done by Pirchegger \& Wagenhofer, (1999).They identified four IFR dimension: content, timeliness, technology and user support. The idea was shared by others authors (Lybaert, (2000), Davey \& Homkajohn, (2004), Chan \& Wickramasinghe, (2006), Pervan, (2006), Celik and al. (2006)). In other way, FASB, (2000) proposed that IFR is composed in two dimensions: content and format presentation. This classification was been used by many researchers (Debreceny and al. (2004), Xiao and al. (2004) and Kelton \& Yang, (2008)...).

Marston \& Polei, (2004) consider that Pirchegger \& Wagenhofer' instrument is a very comprehensive checklist for the evaluation of Web sites.

In this study, we calculate Web based disclosure index, evaluating the extent of financial information published on the European companies' Web sites. This index is defined from Pirchegger \& Wagenhofer, (1999) criteria. They are content, timeliness, technology and user support.
We elaborate a checklist instrument, included 133 information items (table 4):

- Content: Web sites content includes company information and data. It integrated financial information, shareholders' information, social responsibility and business information, (Davey \& Homkajohn, (2004)).

European companies should complete European directive requirements, concerning the financial transparence. According to the 2004/109/CE directive, companies traded on a European regulated market should publish their regulatory information through papers and electronic mean, such as a corporate Web site. Regulatory information includes periodic information, ongoing information and others required information addressed to holders on a regulated markets. However, these companies announce others additional information, which exceeded the transparency directive requirements. There were considered voluntary information.

Web Content composes in regulatory and voluntary information.

- Timeliness: Web site offers to companies the possibility of rapid and updating information in real time. The rapidity helps users to navigate on the Web and make efficient decisions. It includes for example press releases, forward looking statements..., (Davey \& Homkajohn, (2004)).

- Technology: Pirchegger \& Wagenhofer, (1999) define this technology as "the extent to which the companies under investigation make use of some of the more advanced features". Technology enhance the quality of the financial reporting and facilitate communication though corporate sites. Technology items incorporate moving pictures, graphics, and use of multimedia technologies....

- User support: It measures the design and layout of the Web sites, such as the search and navigation tools and number of clicks...

We complete voluntary disclosure, timeliness, technology and user support items according to the checklists instruments developed by previous studies, which deals the Web based financial disclosure in the European countries.

Total Web disclosure index (TWDI) was calculated as follows:

$$
\text { TWDI }=\frac{\text { total Score obtained by firm }}{\text { Number total of items }}(1)
$$

Table 4: Web Based Financial Disclosure Dimensions

\begin{tabular}{l}
\hline Items composition \\
\hline Dimension 1:Websites Content \\
I- Regulated Information. \\
1- Periodic Information. \\
A- Annual Information. \\
1- Annual financial report. \\
2- Annual balance sheet of the parent company. \\
3- Annual of comprehensive income of the parent company. \\
4- Annual statement of cash flow of the parent company. \\
5- Notes to the annual company financial statements. \\
6- Annual management report of the parent company. \\
7- Annual auditor report certified the company annual statements. \\
8- Annual statements of persons responsible with the company \\
9- Consolidated annual balance sheet. \\
10- Consolidated annual comprehensive income. \\
11- Consolidated annual cash flow. \\
12- Notes to the consolidated annual financial statements. \\
13- Annual auditor report certified consolidated annual statements. \\
14- Annual consolidated management report. \\
15- Information concerning the corporate remuneration policies.
\end{tabular}


16- Compensation of administration (or supervisory) body president.

17- Compensation of other administration (or supervisory) body members.

18- CEO compensation.

19- Other management members' compensation.

20- "Stock-Options" compensation.

21- Other remuneration formats (benefits in kind)

22- Presentation of "Annual information" in English language.

B- Interim Information.

23- Interim financial report.

24- Interim balance sheet of the parent company.

25- Interim comprehensive income of the parent company.

26- Interim statement of cash flow of the parent company.

27- Notes to the interim company financial statements.

28- Interim management report of the parent company.

29- Annual auditor report certified the company interim statements.

30- Interim statements of persons responsible with the company.

31- Consolidated interim balance sheet.

32- Consolidated interim comprehensive income.

33- Consolidated interim cash flow.

34- Notes to the consolidated interim financial statements.

35- Interim consolidated management report.

36- Annual auditor report certified the consolidated annual statements.

37- Condensed profit and loss account.

38- Interim management statements.

39- Quarterly financial reports.

40- Presentation of "Interim Information" in English language.

2- Ongoing information.

A- Information about major holdings.

41- Information concerning the notification of the proportion of firm voting rights.

42- Information concerning the corporate share acquisition.

43- Information concerning the corporate share disposal.

44- Information concerning the change the rights attaching to the various classes of share issued by the firm.

45- Information concerning the new loan issues (in particular guarantee or security).

46- Presentation of "Major Holdings Information" in English Language.

B- Information requirement for issuers whose shares are admitted to trading on a regulated market.

47- Information concerning the agenda of shareholders meeting.

48- Information concerning the total number of share.

49- Information concerning the total number of voting rights.

50- Proxy form authorizing the vote to the meeting.

51- Notice concerning the meeting.

52- Circulars concerning the allocation and payment of dividends.

53- Circulars concerning the issue of new shares.

54- Presentation "information requirements" in English language.

3 - Presence of filing and storage system.

55- Existence of filing and storage system

56- Continuous financial data storage.

II. Voluntary information.

1- Financial information.

A- Investor relations.

57- Presence of "investor relations" sector on the Web page.

58- Analysts forecast lists.

59- Post addresses, reserved to investor relation.

60- Telephone number, reserved to investor relation.

61- E-mail addresses, reserved to investor relation.

62- Link to stock data on exchanges market Website.

B- Other financial information.

63- Financial ratios.

64- Key indicators.

65- Share price performance in relation to stock market performance.

2- Non- financial information.

A- General Information.

66- Firm Historic.

67- Chairman's message.

68- Presentation of company' activities.

69- Status.

70- Organizational chart.

B- Corporate governance.

71- Presentation of corporate governance section.

72- Internal control and corporate governance reports.

73- Supervisory board composition.

74- Supervisory board functioning.

75- Independence of board members.

76- Qualification of board members.

77- Experience of board members.

78- Information about board committee.

79- Information about management board members.

80- Internal and external auditors' honoraries.

81- Corporate governance code.

82- Ethics code.

83- Articles of association. 
84- Information about risk.

C- Environmental and social responsibility information.

85- Existence of environmental and social responsibility information section on Web sites.

86- Environmental responsibility reports.

87- Social responsibility reports.

88- Sustainable development.

89- Information about social responsibility.

90- Information about human resources.

91- Information about innovation/technology.

92- Certificate of good environmental behavior ISO 14001.

93- Certificate of high quality ISO 9001.

94- Information about others certificate.

D- Segmental information.

95- Company products/services.

96- Products/services perspectives.

97- New products perspectives.

98- Total turnovers in current year.

99- Segmental information by line business.

100 - Segmental information by region.

101- Concurrence.

102- Turnovers prevision.

103- E-commerce.

104- Publicity.

Dimension2: Website Timeliness.

105- Date of last update of Website.

106- Current press releases.

107- News.

108- Current share price.

109- Financial calendar.

110- Financial calendar update.

111- Newsletter.

112- E-mail Alerts.

113- Rapid access to "investor relation" section.

Dimension3: Website technology.

114- Financial reports in processable format (PDF, HTML, Excel....).

115- Financial data in processable format (PDF, HTML, Excel....).

116- Hyperlinks inside the annual report.

117- Hyperlinks from the annual report to others Websites section.

118- Hyperlinks related financial data.

119- Graphics.

120- Audio/video file.

121- Call conference.

122- Data in XBRL format.

Dimension 4: Website user support.

123- Sitemap.

124- Loading time of the Web site b 10 seconds.

125- Frequently Asked Questions (FAQ).

126- Help site.

127- Internal search engine.

128- Pull-down menu.

129- Click-over menu.

130- Next- previous buttons to navigate sequentially.

131- One click to get to investor relation section.

132- Mailing list.

133- Contact to "Web master".

\subsection{Exogenous and control variables}

Following to previous studies, we identified exogenous variables, which there are related to firm specific characteristics:

- Firm size (TA. ENT): this variable is measure by the natural logarithm of the total assets, using by several studies such as Ashbaugh and al. (1999), Almilia, (2009).

- Profitability (ROE): measured by the return on equity (ROE). This measurement was also used by Marston \& Polei, (2004), Kelton \& Yang, (2008).

- Liquidity (LIQUI): is measured by ratio of the current assets on the current liabilities, (Hossain and al. (2012)).

- Leverage (LEVR): correspond to the ratio of total debt on the total assets, (Turrent \& Ariza, (2012))

- Concentration ownership (CON.OWN): is measured by the percentage of stock held by principal shareholders, (Abdelsalam \& Street 2007, Abdelsalam and al. 2007)

- Information technological sector (IT.SEC): is measured by a dummy variable, noted 1 if the group operated on the Information technological sector (Xiao and al. 2004, Boubaker and al. 2012)
Previous studies showed that others organizational factors can explain the IFR practices, such as firm age and auditor type:

- Firm age (Age): Gandia, (2008) considers that older firms are likely to adopt voluntary disclosure strategic, lower costs. There can support processing and disseminating disclosure costs than younger firms. There are more likely to disclose more voluntary information on their Web site, (Hossain and al. 2012, Pozniak, 2013). Age firm is measured by the natural logarithm of firm activity' number years, (Momany\& Pillai 2013, Pozniak 2013).

- Auditor type (BIG 4): Xiao and al. (2004) argue that international auditor (Big4) as change agent can facility the innovation 'diffusion such as financial reporting on line. They can encourage firms to utilize a Web site as a channel of financial reporting and disclose more information on their Web, (Bonson \& Escobar, (2006)). Auditor type is measured by binary variable 1 if the group was audited by Big 4, o if not, (Momany \& Pillai, (2013)). 


\subsection{Econometrical model}

The following linear regression model to examine the association between firm specific characteristics and Web based financial disclosure.
WSDI $=\beta_{0}+\beta_{1}$ FIR.SIZE $+\beta_{2}$ ROE $+\beta_{3}$ LIQU $+\beta_{4}$ LEVR $+\beta_{5}$ CON. OWN $+\beta_{6}$ IT.SEC $+\beta_{7}$ AGE $+\beta_{8}$ BIG $4+\varepsilon$ (2)

Table $n^{\circ} 4$ describes the identification and the measurement of endogenous and exogenous variable in this study:

Table 5: variable Measurement

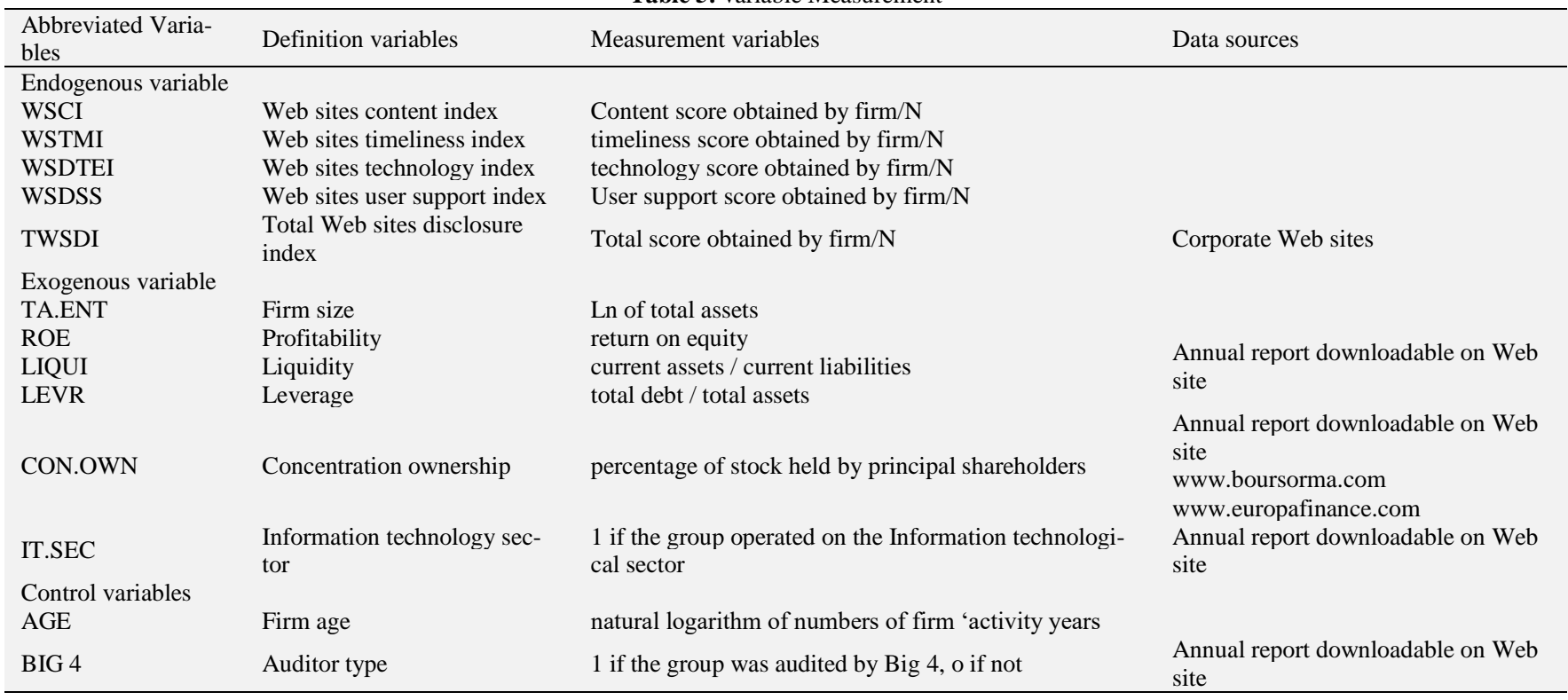

\section{Empirical findings}

We discuss the empirical results in this section, which presents descriptive, multicollinearity and multivariate analysis

\subsection{Descriptive analysis}

Table 6 illustrates descriptive statistics of level of components' financial and business disclosure though corporate European
Websites. In general, the level of Web disclosure varies to country from other.

European companies accord more importance to content and timeliness Websites than other components' site.

Table $n^{\circ} 7$ provides descriptive statistics of exogenous continuous and binary variables.

In general, European groups are large corporation (firm size 'mean is more 17), which a high profitability, liquidity and leverage levels. Table 6 indicates that European groups operate on other sector than technology and major of them are audited by a BIG 4 .

Table 6: Web Disclosure Practices

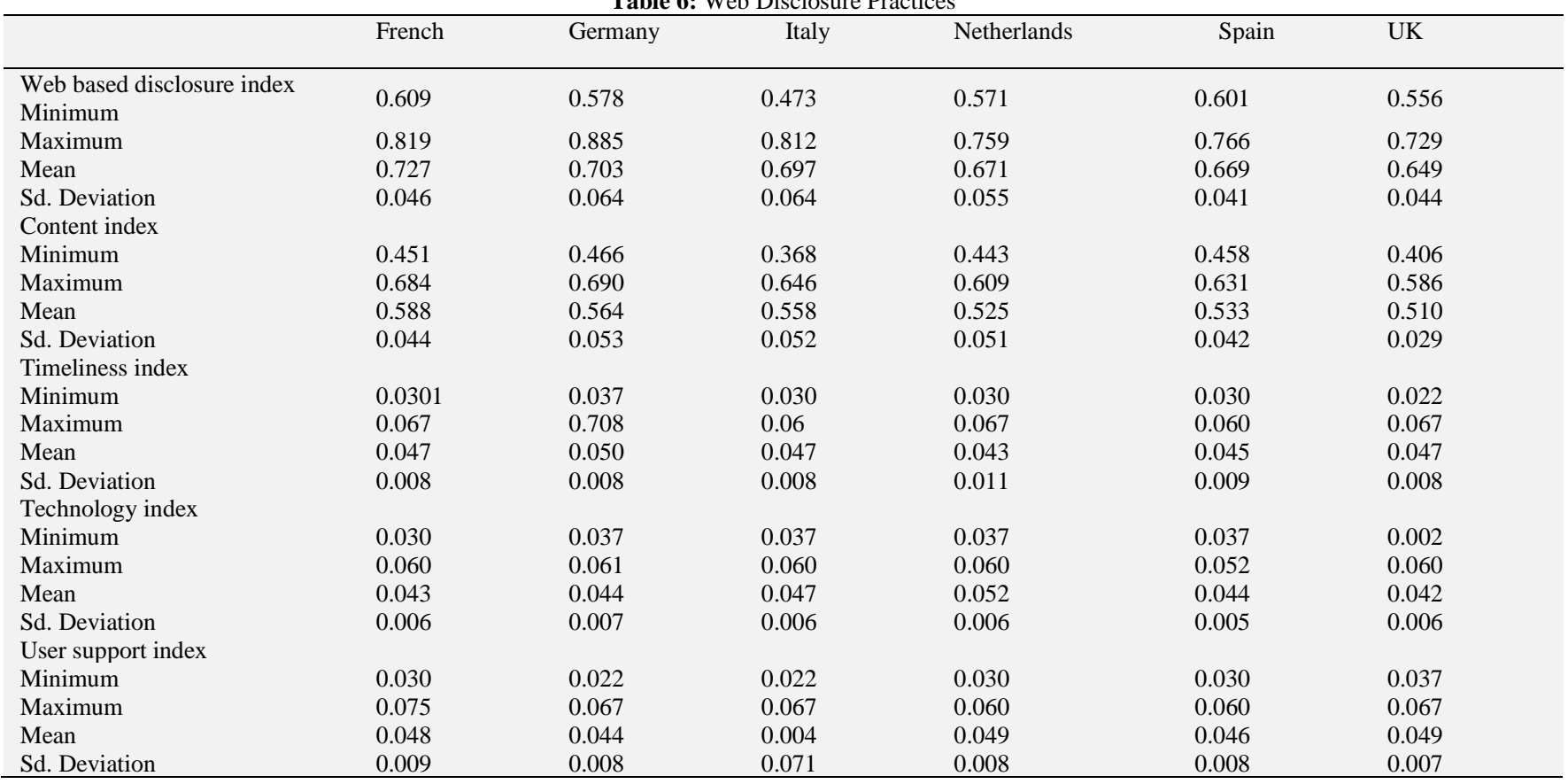


Table 7: Descriptive Statistics of Explanatory Variables

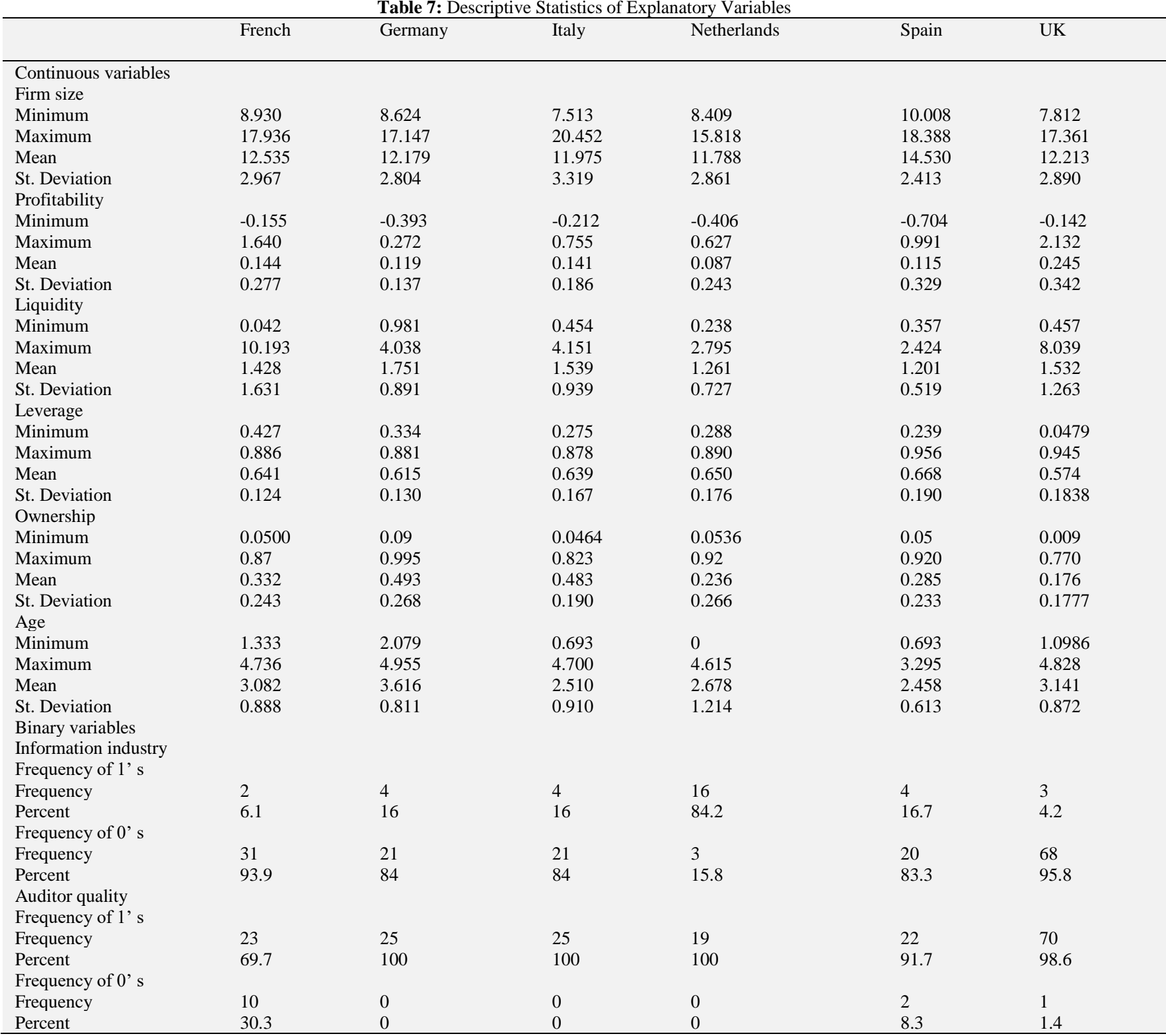

\subsection{Multicollinearity analysis}

Multicollinearity in the explanatory variables has been diagnosed through analyses of correlation matrix, variable inflation factors (VIF) and tolerance.

We established a Pearson correlation matrix. It reveals that all correlation coefficients are below 0.8 (Kennedy, (1985), Bryman \& Cramer, (1997)). All VIF values are below 10 and tolerance values are bigger 0.1 . Also, there is no a Multicollinearity problem between exogenous variables.

\subsection{Multivariate analysis}

We specify the multiple regression approach appropriated to analyzing determining factors of Web disclosure and we interpret multiple regression results for our models. There are: Web content, timeliness, technology, user support and total Web disclosure index models.

\subsubsection{Linear regression methods}

An Ordinary Least Squares (OLS) regression, as a multivariate regression method was used to test the relationship between firm specific characteristics and financial disclosure. But, the application of the OLS method is inappropriate, relating to the construc- tion of financial scores and index, continuous variables ranged between 0 and 1 .

In the case of disclosure studies, the principal dilemma is that direction of the relation between continuous dependent and independent variables is not known through assumed no linear and monotonic. It result the violation of the regression assumptions, (Cooke 1998, Haniffa \& Cooke 2002).

The suggestion to transform continuous and independent variables was performed.

This transformation might assume that the errors are normally distributed, (Cooke, (1998)).

Two regression techniques were applied by the prior and recent accounting studies (Abdelsalam and al. 2007, Aly and al. 2010, Abughazaleh and al. 2012...): full rank and normal scores transformations.

- $\quad$ Full rank transformation: this method consists to range variable with $\mathrm{n}$ observations from 0 to 1 and placed the observations from the smallest to largest. According to Lang \& Lundholm, (1993), ranks scores were calculated using this formulation:

$$
\text { Percentile rank }=\frac{\text { Rank }-1}{\text { Number of companies-1 }}
$$

Normal scores transformation: This transformation is achieved by dividing the normal distribution into the number of observations plus one segment on the basis that each segment has equal probability, (van der Waerden, $(1952,1953)$. 
Normality, Linearity and Homoscedasticity assumptions can be checked by normality plots such as Q-Q plots and histograms of dependant variables. Further, Normality test can be examined again by skewness, kurtosis and Kolmogorov- Smirnov test (or KS Liliefors test).

We performed the Q-Q plots and histograms and K-S Liliefors test using SPSS 20. The result presumes that violation of normality, linearity and Homoscedasticity assumptions. Consequently, it will be legitimated to adopt a data transformation.

We realized a rank and normal scores transformation, reliable on the SPSS 20.

\subsubsection{Interpretation of results}

We summarize in these flowing tables all OLS regression results of content, timeliness, technology, user support and total Web disclosure index models.

According to Abdelsalam and al. (2007), the following interpretation is basing to full rank transformation regression results.

1) Web sites based content index

Table 8: Content Model Regression

\begin{tabular}{|c|c|c|c|c|c|c|c|c|c|}
\hline \multirow[b]{2}{*}{ Variables } & \multicolumn{3}{|c|}{ Untransformed data } & \multicolumn{3}{|c|}{$\begin{array}{l}\text { Transformed data } \\
\text { Rank transformation }\end{array}$} & \multicolumn{3}{|c|}{ Normal Scores transformation } \\
\hline & $\beta$ & $\mathrm{t}$ & Sig. & $\beta$ & $\mathrm{t}$ & Sig. & $\beta$ & $\mathrm{t}$ & Sig. \\
\hline $\mathrm{C}$ & & 20.486 & 0.000 & & 7.233 & 0.000 & & 4.875 & 0.000 \\
\hline ROE & -0.130 & -1.977 & 0.049 & -0.117 & -1.833 & 0.068 & -0.133 & -2.067 & 0.04 \\
\hline LIQU & -0.027 & -0.392 & 0.696 & 0.024 & 0.358 & 0.72 & 0.007 & 0.105 & 0.917 \\
\hline LEVR & -0.068 & -0.982 & 0.327 & -0.068 & -0.979 & 0.329 & -0.071 & -1.020 & 0.309 \\
\hline CON.OWN & 0.264 & 4.428 & 0.000 & 0.262 & 4.104 & 0.000 & 0.261 & 4.075 & 0.000 \\
\hline AGE & 0.086 & 1.346 & 0.180 & 0.076 & 1.198 & 0.232 & 0.09 & 1.405 & 0.162 \\
\hline BIG 4 & -0.358 & -5.632 & 0.000 & -0.375 & -5.908 & 0.000 & -0.349 & -5.454 & 0.000 \\
\hline $\mathrm{R}^{2}$ & 0.252 & & & 0.267 & & & 0.250 & & \\
\hline $\mathrm{R}^{2}$ adjusted & 0.22 & & & 0.235 & & & 0.218 & & \\
\hline F- ratio & 7.906 & & & 8.545 & & & 7.822 & & \\
\hline F. Sig & 0.000 & & & 0.000 & & & 0.000 & & \\
\hline Durbin- Watson & 1.834 & & & 1.687 & & & 1.760 & & \\
\hline
\end{tabular}

Content Web sites regression model is significant. It explain 22 percent of variation measured by the Adjusted $\mathrm{R}^{2}$ and it is significant at $\mathrm{p}=0.000$, using untransformed and transformed data.

OLS Rank transformation regression indicates that four explanatory variables are significant: profitability $(p=0.049)$, ownership concentration $(\mathrm{p}=0.000)$, information technology sector $(\mathrm{p}=$ $0.066)$ and BIG $4(\mathrm{p}=0.000)$. Contrary to our expectations, we find a significant and negative relationship between firm profitability and content index.

Indeed, contrary to the sign excepted, the coefficient of concentration ownership is positive. Abdelsalam and al. (2007) showed that no significant relationship exists between major ownership and general content index through London companies Web sites.

Our results demonstrated a significant and positive relationship between information technology sector and content index. Infor- mation technology firms are more susceptible to disclose financial information through their sites than others sectors, (Boubaker and al. (2012)).

The coefficient of BIG 4 variable is significant and negative. Xiao and al. (2004) demonstrated that the auditor quality is significantly and positively associated to the Web based content scores of listed Chinese companies.

Thus, we find no evidence of a significant relationship between size firm, liquidity, leverage, age and Web based content index.

2) Web based timeliness index

We not support any significant evidence between firm specific characteristics and the Web sites based timeliness index.

3) Web sites based technology index

Table 9: Timeliness Index Model Regression

\begin{tabular}{|c|c|c|c|c|c|c|c|c|c|}
\hline \multirow[b]{2}{*}{ Variables } & \multicolumn{3}{|c|}{ Untransformed data } & \multicolumn{3}{|c|}{$\begin{array}{l}\text { Transformed data } \\
\text { Rank transformation }\end{array}$} & \multicolumn{3}{|c|}{ Normal Scores transformation } \\
\hline & $\beta$ & $\mathrm{t}$ & Sig. & $\beta$ & $\mathrm{t}$ & Sig. & $\beta$ & $\mathrm{t}$ & Sig. \\
\hline $\mathrm{C}$ & & 9.166 & 0.000 & & 4.726 & 0.000 & & -0.126 & 0.900 \\
\hline FIR.SIZE & -0.088 & -1.197 & 0.233 & -0.098 & -1.355 & 0.177 & -0.086 & -1.189 & 0.236 \\
\hline ROE & 0.000 & -0.005 & 0.996 & 0.033 & 0.454 & 0.651 & 0.029 & 0.399 & 0.69 \\
\hline LIQU & -0.091 & -1.153 & 0.250 & -0.081 & -1.048 & 0.296 & -0.07 & -0.904 & 0.367 \\
\hline LEVR & 0.071 & 0.905 & 0.367 & 0.077 & 0.976 & 0.330 & 0.082 & 1.038 & 0.300 \\
\hline CON.OWN & 0.047 & 0.65 & 0.517 & 0.04 & 0.547 & 0.585 & 0.071 & 0.98 & 0.328 \\
\hline IT.SEC & -0.097 & -1.347 & 0.180 & -0.114 & -1.589 & 0.114 & -0.069 & -1.337 & 0.183 \\
\hline AGE & -0.006 & -0.076 & 0.939 & 0.006 & 0.079 & 0.937 & 0.011 & 0.148 & 0.882 \\
\hline BIG 4 & 0.025 & 0.351 & 0.726 & 0.032 & -0.445 & 0.657 & 0.022 & 0.305 & 0.760 \\
\hline $\mathrm{R}^{2}$ & 0.044 & & & 0.048 & & & 0.043 & & \\
\hline $\mathrm{R}^{2}$ adjusted & 0.004 & & & 0.007 & & & 0.002 & & \\
\hline F- ratio & 1.090 & & & 1.184 & & & 1.057 & & \\
\hline F. Sig & 0.372 & & & 0.310 & & & 0.396 & & \\
\hline Durbin- Watson & 1.781 & & & 1.848 & & & 1.784 & & \\
\hline
\end{tabular}


Table 10: Technology Index Model Regression

\begin{tabular}{|c|c|c|c|c|c|c|c|c|c|}
\hline \multirow[b]{2}{*}{ Variables } & \multicolumn{3}{|c|}{ Untransformed data } & \multicolumn{2}{|c|}{$\begin{array}{l}\text { Transformed data } \\
\text { Rank transformation }\end{array}$} & \multicolumn{4}{|c|}{ Normal Scores transformation } \\
\hline & $\beta$ & $\mathrm{t}$ & Sig. & $\beta$ & $\mathrm{t}$ & Sig. & $\beta$ & $\mathrm{t}$ & Sig. \\
\hline $\mathrm{C}$ & & 11.648 & 0.000 & & 4.631 & 0.000 & & -1.204 & 0.230 \\
\hline FIR.SIZE & -0.191 & -2.684 & 0.008 & -0.149 & -2.143 & 0.033 & -0.153 & -2.194 & 0.029 \\
\hline ROE & -0.022 & -0.309 & 0.758 & -0.194 & -2.784 & 0.006 & -0.157 & -2.262 & 0.025 \\
\hline LIQU & 0.113 & 1.473 & 0.142 & 0.106 & 1.424 & 0.156 & 0.091 & 1.213 & 0.227 \\
\hline LEVR & -0.016 & -0.212 & 0.833 & 0.004 & 0.05 & 0.96 & 0.008 & 0.105 & 0.917 \\
\hline CON.OWN & 0.18 & 2.566 & 0.011 & 0.167 & 2.398 & 0.017 & 0.195 & 2.811 & 0.005 \\
\hline AGE & -0.023 & -0.326 & 0.745 & -0.002 & -0.027 & 0.979 & 0.02 & 0.282 & 0.779 \\
\hline BIG 4 & 0.074 & 1.070 & 0.286 & 0.094 & 1.353 & 0.178 & 0.084 & 1.204 & 0.230 \\
\hline $\mathrm{R}^{2}$ & 0.105 & & & 0.128 & & & 0.120 & & \\
\hline $\mathrm{R}^{2}$ adjusted & 0.067 & & & 0.091 & & & 0.083 & & \\
\hline $\mathrm{F}-$ ratio $=$ & & & & & & & 3.025 & & \\
\hline F. Sig & 0.007 & & & 0.001 & & & 0.002 & & \\
\hline Durbin- Watson & 1.518 & & & 1.541 & & & 1.550 & & \\
\hline
\end{tabular}

The technology index model is significant at 0.007 , employing both untransformed and transformed data. According to the OLS rank transformation regression, we find that firm size, profitability and concentration ownership are significantly related to technology index.

Contrary to the sign excepted, the results do not verify the positive influence of firm size and profitability to the technology index.

In opposition in our expectations, we find that ownership is significantly and positively related to the level of Web sites technology. According to this result, we can conclude that principal shareholders encourage their companies to investigate more on the Web site technology.
They underline the importance of technology, as a principal of IFR dimension, helping the users to acquire reliable electronic information.

4) Web based User support index

Table $n^{\circ} 11$ illustrates that one coefficient is significant: the presence of major shareholders affects significantly and negatively Web based user support index.

In addition, we find no significant relationship between others specific firm characteristics and user support index.

5) Total Web disclosure index

Table 11: User Support Index Model Regression

\begin{tabular}{|c|c|c|c|c|c|c|c|c|c|}
\hline \multirow[b]{2}{*}{ Variables } & \multicolumn{3}{|c|}{ Untransformed data } & \multicolumn{3}{|c|}{$\begin{array}{l}\text { transformed data } \\
\text { Rank transformation }\end{array}$} & \multicolumn{3}{|c|}{ Normal Scores transformation } \\
\hline & $\beta$ & $\mathrm{t}$ & Sig. & $\beta$ & $\mathrm{t}$ & Sig. & $\beta$ & $\mathrm{t}$ & Sig. \\
\hline $\mathrm{C}$ & & 9.039 & 0.000 & & 5.567 & 0.000 & & -0.028 & 0.977 \\
\hline ROE & -0.081 & -1.101 & 0.272 & -0.102 & -1.414 & 0.159 & -0.098 & -1.363 & 0.175 \\
\hline LIQU & -0.052 & -0.661 & 0.509 & -0.045 & -0.588 & 0.557 & -0.027 & -0.356 & 0.722 \\
\hline LEVR & 0.103 & 1.327 & 0.186 & 0.117 & 1.487 & 0.139 & 0.110 & 1.404 & 0.162 \\
\hline CON.OWN & -0.169 & -2.350 & 0.020 & -0.191 & -2.650 & 0.009 & -0.183 & -2.548 & 0.012 \\
\hline IT.SEC & 0.076 & 1.071 & 0.286 & 0.063 & 0.889 & 0.375 & 0.081 & 1.139 & 0.256 \\
\hline AGE & 0.055 & 0.766 & 0.445 & 0.046 & 0.644 & 0.521 & 0.06 & 0.821 & 0.407 \\
\hline BIG 4 & -0.016 & -0.220 & 0.826 & 0.010 & 0.140 & 0.889 & -0.008 & -0.109 & 0.931 \\
\hline $\mathrm{R}^{2}$ & 0.057 & & & 0.064 & & & 0.061 & & \\
\hline $\mathrm{R}^{2}$ ajusted & 0.017 & & & 0.024 & & & 0.021 & & \\
\hline F- ratio & 1.427 & & & 1.609 & & & 1.520 & & \\
\hline F. Sig & 0.188 & & & 0.125 & & & 0.125 & & \\
\hline Durbin- Watson & 1.646 & & & 1.644 & & & 1.617 & & \\
\hline
\end{tabular}

Table 12: Web Disclosure Index Model

\begin{tabular}{|c|c|c|c|c|c|c|c|c|c|}
\hline \multirow[b]{2}{*}{ Variables } & \multicolumn{3}{|c|}{ Untransformed data } & \multicolumn{3}{|c|}{$\begin{array}{l}\text { Transformed data } \\
\text { Rank transformation }\end{array}$} & \multicolumn{3}{|c|}{ Normal Scores transformation } \\
\hline & $\beta$ & $\mathrm{t}$ & Sig. & $\beta$ & $\mathrm{T}$ & Sig. & $\beta$ & $\mathrm{t}$ & Sig. \\
\hline $\mathrm{C}$ & & 23.616 & 0.000 & & 7.767 & 0.000 & & -4.523 & 0.000 \\
\hline FIR.SIZE & -0.060 & -0.903 & 0.368 & -0.073 & -1.133 & 0.259 & -0.021 & -0.323 & 0.474 \\
\hline ROE & -0.136 & -2.038 & 0.043 & -0.134 & -2.075 & 0.039 & -0.015 & -2.303 & 0.022 \\
\hline LIQU & -0.034 & -0.476 & 0.635 & 0.033 & 0.417 & 0.634 & 0.017 & 0.238 & 0.818 \\
\hline LEVR & -0.039 & -0.546 & 0.586 & -0.037 & -0.526 & 0.599 & -0.035 & -0.489 & 0.626 \\
\hline CON.OWN & 0.268 & 4.102 & 0.000 & 0.241 & 3.728 & 0.000 & 0.246 & 3.793 & 0.000 \\
\hline IT.SEC & 0.120 & 1.851 & 0.066 & 0.551 & 2.423 & 0.016 & 0.131 & 2.035 & 0.043 \\
\hline AGE & 0.054 & 1.294 & 0.197 & 0.086 & 1.343 & 0.181 & 0.082 & 1.258 & 0.210 \\
\hline BIG 4 & -0.323 & -4.998 & 0.000 & -0.353 & -5.500 & 0.000 & -0.330 & -5.097 & 0.000 \\
\hline $\mathrm{R}^{2}$ & 0.224 & & & 0.250 & & & 0.232 & & \\
\hline $\mathrm{R}^{2}$ ajusted & 0.191 & & & 0.218 & & & 0.199 & & \\
\hline F- ratio & 6.794 & & & 7.844 & & & 7.086 & & \\
\hline F. Sig & 0.000 & & & 0.000 & & & 0.000 & & \\
\hline Durbin- Watson & 1.828 & & & 1.672 & & & 1.740 & & \\
\hline
\end{tabular}

Table $n^{\circ} 12$ showed that the $\mathrm{R}^{2}$ adjusted of this model verify that the explanatory variables explain the variance of total index by 25 percent and this model is significant at 0.000 , examining both untransformed, rank and normal scores transformation.

Full rank transformation regression indicates that firm size is not significant related to the Web disclosure index.
This finding is consistent with Pichegger \& Wagenhofer, (1999), Nurunnabi \& Hossain, (2012) and Turrent \& Ariza, (2012). We not support the first hypothesis (H1).

In opposition to our expectations, the OLS results indicate that profitability is significantly and negatively associated with this index. 
Ashbaugh and al. (1999), Ismail, (2002) and Elsayed and al. (2010) not support a significant evidence related profitability and total Web disclosure index. We reject the second hypothesis (H2). We not find a significant relationship between firm liquidity and leverage and the extent of Web financial disclosure. The results are consistent with Abouerta \& Hussien, (2017).

The $\mathrm{H} 3$ and $\mathrm{H} 4$ hypothesis are not supported.

Contradictory to the signs expected, the finding signals that ownership structure is significantly and positively associated to the corporate Web disclosure level. H5 hypothesis is not supported The multivariate analysis information technology sector is significantly and positively related to the Web disclosure level. This findings confirms with Xiao and al, (2004) and Boubaker and al. (2012)

We support that this variable influence the financial information diffusion through European Web sites and we confirms our H6 hypothesis.

Auditor quality, as a control variable, affects significantly and negatively the Web disclosure level.

\section{Conclusion}

The main objective of this study is to analyze Web disclosure practices. Specially, we examine the relationship between firm specific characteristics and the level of financial disclosure through corporate Web sites of 197 listed European groups.

We realize An Ordinary Least Squares (OLS) regression, which the continuous variables needs an appropriate adjustments. According to the previous accounting literature, we accomplish Web disclosure and continuous explanatory variables' transformation. There are full rank and normal scores transformation.

OLS rank scores regression showed that profitability, ownership concentration, information technology sector and BIG 4 significantly related to the Web content index. Firm size, profitability and concentration ownership influence significantly the Web technology index and we find a significant relationship between the presence of major shareholders and user support level

We determine that four exogenous variables affect significantly the Web disclosure level. However, information technology sector is only significantly and positively associated with the total Web disclosure. Also, we support that this variable as the factor identified the Web disclosure practice in Europe.

This study is subject to some limitation. We consider that number of countries selected is inappropriate to demonstrate the corporate Web disclosure practices between continental and Anglo-Saxon countries. That also, we can't generalize our findings, with its proper to European countries, which are imposed to apply the transparency directive requirements.

Further researchers will examine and compare the Web financial disclosure practice in others contexts such as in MENA countries.

\section{References}

[1] Abdalmuttaleb MA \& Al- Sartawi, M (2016), measuring the level of online financial disclosure in the Gulf cooperation council countries. Corporate ownership and control, 1, 547-558.

[2] Abdelsalam, OH \& Street, DL (2007), corporate governance and the timeliness of corporate internet reporting by UK listed companies. Journal of International Accounting, Auditing and taxation, 16, 111-130. https://doi.org/10.1016/j.intaccaudtax.2007.06.001.

[3] Abdelsalam, OH, Bryant, MS \& Street, DL (2007), An examination of the comprehensiveness of corporate internet reporting provided by London-listed companies. Journal of International Accounting Research, 6-2, 1-33. https://doi.org/10.2308/jiar.2007.6.2.1.

[4] Aboutera, LA\& Hussien, A (2017), Determining of Internet financial reporting by Egyptian Companies. Research journal of finance and accounting, 8- 10, 28-39.

[5] AbuGhazaleh, NM Qasim, A \& Roberts, C (2012), The determinants of Web-based Investor Relations Activities by Companies Operating in Emerging Economies: the case of Jordan. The Journal of Applied Business Research, 28-2, 209226.https://doi.org/10.19030/jabr.v28i2.6842.
[6] Ahmed, K \& Courtis, JK (1999), Associations between corporate characteristics and disclosure levels in annual reports: a meta- analysis. British Accounting Review, 31, 35-61. https://doi.org/10.1006/bare.1998.0082.

[7] Al-Haybat, KA, Abdulrahman, NIY\& Award, AMM (2013), Model for the Adoption of smart Mobile devices in corporate financial reporting. International journal of business and management, 8-4, 116. https://doi.org/10.5539/ijbm.v8n24p1.

[8] Aljifri, K, Alzarouni, A, Ng, C. \&Tahir, MI (2014), the association between firm Characteristics and corporate financial disclosure: Evidence from UAE companies. The International Journal of Business and Finance Research, 8- 2, 101-123.

[9] Allam, A \& Lymer, A (2003), Developments in Internet Financia Reporting: Review and Analysis Across Five Developed Countries. The International Journal of Digital Accounting Research, 3- 6, 165-199. https://doi.org/10.4192/1577-8517-v3 6.

[10] AlMatrooshi, SAS, Al-Sartawi, AMAM \& Sanad, Z (2016), do audit committee Characteristics of Bahraini listed companies have an effect on the level of Internet financial reporting. Corporate Ownership and control Journal, 3-2, 130-146 https://doi.org/10.22495/cocv13i3p12.

[11] Almilia, LS (2009), Determining factors of Internet financial reporting in Indonesia». Accounting and taxation, 1-1, 87-89.

[12] Alsaeed, K (2005), the association between firm specific characteristics and disclosure: the case of Saudi Arabia. The journal of American academy of business, 7-1, 310-321. https://doi.org/10.1108/02686900610667256.

[13] Alvarez, IG, Sanchez, IG \& Dominguez, LR (2008), Voluntary and disclosed on line: the effect of industry concentration and other explanatory factors. Online Information Review, 23- 5, 596-622. https://doi.org/10.1108/14684520810913990.

[14] Aly, D, Simon, J \&Hussainey, K (2010), Determinants of corporate Internet Reporting: Evidence from Egypt», Managerial Auditing Journal. $25-2$ $182-202$ https://doi.org/10.1108/02686901011008972.

[15] Andrikopoulos, A \& Diakidis, N (2007), financial reporting practices on the Internet the case of companies listed in the Cyprus stock Exchange. Working Paper, www.ssrn.com https://doi.org/10.2139/ssrn.999183.

[16] Arcay, DR \&Vazquez, MF (2005), corporate characteristics, governance rules and the extent of disclosure in Spain. Advance in Accounting, $\quad 1, \quad 299-331$. https://doi.org/10.1016/S08826110(05)21013-1.

[17] Ashbaugh, H, Johnstone, KM \& Warfield, TD (1999), Corporate Reporting on the Internet. Accounting Horizons, 13-3, 241-258. https://doi.org/10.2308/acch.1999.13.3.241.

[18] Bekiaris, M, Psimada, C \&Sergios, T (2014), Internet Financial Reporting quality and corporate characteristics: the case of construction companies listed in Greek and Cypriot stock exchange. European Research Studies, XVII-2, 41.57.

[19] Bollen, L, Hassink, H \&Bozic, G. (2006), Measuring and explaining the quality of Internet investor relations activities: a multinational empirical analysis. Internet Journal of Accounting Information System, 7, https://doi.org/10.1016/j.accinf.2006.04.005.

[20] Bonson, E \& Escobar, T (2006), Digital Reporting in Eastern Europe: an empirical study, International Journal of Accounting In$\begin{array}{lllll}\text { formation } & \text { Systems, } & 7, \quad \mathrm{~N}^{\circ} 4, & \text { pp } & 299-318\end{array}$ https://doi.org/10.1016/j.accinf.2006.09.001.

[21] Bonson, E, Cortijo, C \& Escobar, T (2009), towards the global adoption of XBRL using International financial reporting standards (IFR). International Journal of Accounting Information Systems, 10-4, 46-60. https://doi.org/10.1016/j.accinf.2008.10.002.

[22] Botoson, CA (1997), Disclosure level and the cost of Equity capital. The Accounting Review, 72-33, 323-349.

[23] Boubaker, S, Lakhal, F \&Nekhili, M (2012), the determination of Web-based corporate reporting in France. Managerial, Auditing Journal, 27-2 https://doi.org/10.1108/02686901211189835.

[24] Brennan, N\& Hourigan, D (1998), Corporate reporting on the Internet by Irish companies. Accountancy Ireland, 30-6, 18- 21.

[25] Camfferman, K \& Cooke, T, (2002), An Analysis of disclosure in the annual reports of UK and Dutch companies», Journal of International Accounting Research, 1-1, 3-30. https://doi.org/10.2308/jiar.2002.1.1.3.

[26] Celik, O, Ecer, A \& Karabacak, H (2006), Impact of firm specific characteristics on the web based business reporting: evidence from the companies listed in Turkey. Problems and Perspectives in Management, 4- 3, 100- 133. 
[27] Chan, WK Wickramasinghe, N (2006), Using the Internet for financial disclosure: the Australian experience, Internet Journal Electronic finance, 2- 1, 118-150. https://doi.org/10.1504/IJEF.2006.008841

[28] Chow, CW \& Wong-Boren, A (1987), Voluntary financial disclosure by Mexican corporations. The Accounting Review, 62-2, 533541

[29] Cooke, TE (1989), Disclosure in the corporate annual reports of Swedish companies. Accounting and Business Research, 16-47, 113-124. https://doi.org/10.1080/00014788.1989.9728841.

[30] Cooke, T. E. (1998), " Regression Analysis in Accounting Disclosure Studies», Accounting and Business Research, Volume 28, Issue 3,pp 209-224. https://doi.org/10.1080/00014788.1998.9728910.

[31] Cotter, J, Lokman, N \&Najah, M (2011), Voluntary disclosure research: which theory is relevant?, The Journal of Theoretical Accounting Research, 6-2, 77-95.

[32] Craven, BM \& Marston, CL (1999), Financial reporting on the Internet by leading UK companies. The European Accounting Review, 8- 2, 321-333. https://doi.org/10.1080/096381899336069.

[33] Davey, H \& Homkajohn, K (2004), Corporate Internet reporting: An Asian Example, Problems and Perspectives in Management, 2, 211-217

[34] Debreceny, R, Gray, GL \& Rahman, A (2002), the determinants of Internet financial reporting. Journal of Accounting and Public policy, 21, 371-394. https://doi.org/10.1016/S0278-4254(02)00067-4.

[35] Deller, D, Stubenrath, M \& Weber, C (1999), A survey on the use of the Internet for investor relations in the USA, the UK and Germany, the European Accounting Review, 8-2, 351-364. https://doi.org/10.1080/096381899336087.

[36] Depoers, P (2000), A cost benefit study of voluntary disclosure: some empirical evidence from French listed companies, The European Accounting Review, 4-2, 261-280. https://doi.org/10.1080/09638180050129891.

[37] Dolinsek, T, Tomine, P \&Skerbinjek, AL (2014), Users' perceptions on Internet Financial Reporting, Organizacija, 47-2, 254-266. https://doi.org/10.2478/orga-2014-0019.

[38] Elsayed, ANE, ElMasry, AA \&Elbelltagi, IM (2010), corporate governance, firm characteristics and Internet financial reporting: Evidence from Egyptian listed companies, Corporate Ownership and control, 7- 7, 397-426. https://doi.org/10.22495/cocv7i4c4p1.

[39] Ettredge, M, Richardson, VJ \& Scolz, S (2001), the presentation of financial information at corporate web sites. International Journal of Accounting Information Systems, 1-2, 149-168. https://doi.org/10.1016/S1467-0895(00)00017-8.

[40] Ettredge, M, Richardson, VJ \& Scolz, S (2002), Dissemination of information for investor at corporate Web sites, Journal of Accounting and Public Policy, 21, 357-369. https://doi.org/10.1016/S02784254(02)00066-2.

[41] European Union, (2004), Directive 2004/109/EC of the European parliament and of the council of 15 December 2004 on the harmonization of transparency requirements in relation about issuers whose securities are admitted to trading on a regulated market and amending directive 2001/34/EC, Official Journal of the European Union, L390/38.

[42] Ezat, A \& El-Masry, A (2008), the impact of corporate Governance on the Timeliness of corporate Internet Reporting by Egyptian listed companies. Managerial Finance, 34-2, 848-867. https://doi.org/10.1108/03074350810915815.

[43] Financial Accounting Standards Board, (2000), Business Reporting Project Electronic distribution of Business information, www.fasb.org.

[44] Field, A (2009), Discovering statistics using SPSS, Thrid edition, Sage publication, London.

[45] Gandia, JL (2008), Determinants of Internet-based corporate governance disclosure by Spanish listed companies, online information Review,

$32-6$,

$791-817$ https://doi.org/10.1108/14684520810923944.

[46] Giner, B, Arce, M, Cervera, N \& Ruiz, A (2003), Invectivas para la divulgcionvolumtaria de informacion: evidencia empirica sobre la informecionsegmentada, Revisto Europea de direccion y Economica de la Empresa, 12-4, 69-86.

[47] Gowthorpe, C \&Amat, O (1999), External reporting of accounting and financial information via the Internet in Spain, the European Accounting Review, 8-2, 365-371. https://doi.org/10.1080/096381899336096

[48] Gray, GL \& Debrency, RS (1997), Corporate reporting on the Internet: Opportunities and Challenges. Paper presented at the 7 th Asian- Pacific conference on International Accounting Issues, Bangkok.
[49] Gul, FA \& Leung, S (2004), Board Leadership, outside directors' expertise and Voluntary corporate disclosure, Journal of Accounting and Public Policy, 23, 351-379. https://doi.org/10.1016/j.jaccpubpol.2004.07.001.

[50] Haniffa, RM \& Cooke, TE (2002), Culture corporate governance and disclosure in Malaysian corporation. Abacus, 38-3, 317-349.

[51] Hassan, MK (2015), corporate governance, audit committee and the Internet reporting on strategic information by UAE non-financial listed firms. Accounting and Management Information systems, 14 3, 508-545.

[52] Henchiri, JE (2011), Voluntary Web-based disclosures by Moroccan and Tunisian companies, EuroMed Journal of Business, 6-2 153-17. https://doi.org/10.1108/14502191111151241.

[53] Hossain, M, Momin, MA \& Leo, S (2012), Internet financial reporting and disclosure by listed companies: Further evidence from an emerging country, corporate ownership and control, 9-4, 351366.

[54] Ismail, TH (2002), An Empirical investigation of factors influencing Voluntary disclosure of financial information on the Internet in the CGG countries, working paper, www.ssrn.com. https://doi.org/10.2139/ssrn.420700.

[55] Ismail, TH \& Sobhy, NM (2009), Determinants of auditors' perceptions of the Work needed in the audit of Internet-based financial reports in Egypt, Journal of Applied Accounting Research, 10- 2 132-150.

[56] Jensen, M \&Meckling, W (1976), Theory of the firm: Managerial behavior, agency costs and ownership structure, Journal of financial Economics, 3, 305-360. https://doi.org/10.1016/0304 405X(76)90026-X.

[57] Kelton, AS \& Yang, Y (2008), The Impact of Corporate Governance on Internet financial reporting, Journal of Accounting and $\begin{array}{lll}\text { Public } \quad \text { Policy, } & \text { 27-1, } & \end{array}$ https://doi.org/10.1016/j.jaccpubpol.2007.11.001

[58] Lang, M \& Lundholm, R (1993), Cross Sectional determinants of Analysts Ratings of corporate disclosure. Journal of Accounting Research, 31, 246-271. https://doi.org/10.2307/2491273.

[59] Larran, M \& Giner, B (2002), the use of the Internet for corporate reporting by Spanish. The International Journal of Digital Accounting Research, 2-1, 35-82.

[60] Lowers, TJ \& Pasewark, WR (1996), The Internet: Changing the way corporations tell their story, CPA Journal, 66- 11.

[61] Lybaert, N (2002), On-Line financial reporting. An Analysis of the Dutch listed firms, The International Journal of Digital Accounting Research, 2-4, 195-234.https://doi.org/10.4192/1577-8517-v2 7.

[62] Lymer, A \& Lallberg, A (1997), Corporate reporting and the Internet- a survey and commentary on the use of the WWW in corporate reporting in the UK and Finland, Paper presented at EAA'97, Graz, Austria, April 23-25 Th 1997.

[63] Lymer, A, Debrency, R \&Gray, GL (1999), Business Reporting on the Internet, International Accounting Standards Committee (IASC).

[64] Marston, C \&Polei, A (2004), Corporate reporting on the Internet by German companies, International Journal of Accounting Information Systems, 5-1, 285-311.

[65] Meek, GK, Roberts, CB \& Gray, SJ (1995), Factors influencing voluntary annual report disclosures By US., UK and Continental European multi-national corporations, Journal of International Business Studies, 26, 555-572.

[66] Momany, MT \& Pillai, R (2013), Internet financial reporting in UAE- Analysis and implications global review of accounting and finance, 4-2, 142-160.

[67] Nurunnabi, M \& Hossain, MA (2012), The Voluntary disclosure of Internet financial reporting (IFR) in an emerging economcy: Case of digital Bangladesh, Journal of Asia Business Studes, 6-1, 17-42. https://doi.org/10.1108/15587891211190688

[68] Omran, MA \& Ramdhony, D (2016), Determinants of internet financial reporting in African markets: the case of Mauritius, the journal of developing areas, 50-4, 1-18. https://doi.org/10.1353/jda.2016.0150.

[69] Owusu-Ansah, S (1998), the impact of corporate attributes on the extent of mandatory disclosure and reporting by listed companies in Zimbabwe, The International journal of Accounting, 33-5, 605-631 https://doi.org/10.1016/S0020-7063(98)90015-2.

[70] Oyelere, P, Lasward, F\& Fisher, R (2003), Determinants of Internet financial reporting by New Zealand companies, Journal of International Financial Management and Accounting, 14- 1, 26-36. https://doi.org/10.1111/1467-646X.00089.

[71] Paturel, R, Matoussi, H \& Jouini, I (2006), Les motivations de la communication financière des entreprises françaises et britanniques 
à travers le Web », $5^{\text {iéme }}$ colloque international de la recherche en science.

[72] Pervan, I (2006), Voluntary financial reporting on the InternetAnalysis of the practice of Croatian and Slovene listed joint stock companies, financial theory and Pratique, 30-1, 1-27.

[73] Petravick, S \& Gillet, JW (1996), financial reporting on the World Wide Web, Management Accounting, 78- 5, 26-29.

[74] Pirchegger, B \& Wagenhofer, A (1999), financial information on the Internet: a survey of the Homepages of Austrian companies The European Accounting Review, 8-2, 383-395. https://doi.org/10.1080/096381899336113.

[75] Pozniak, L (2013), Internet financial communication evidence from unregulated markets in Brussels and Paris. International journal of Business and finance Research, 7-5, 107-122.

[76] Prencipe, A (2004), Proprietary costs and determinants of voluntary segment disclosure: evidence from Italian listed companies, European Accounting Review, 13- 2, 319-340.

[77] Prentice, RA, Richardson, VJ \& Scholz, S (1999), Corporate Web site Disclosure and Rule 10 b-5: An empirical evaluation. American Business Low Journal, 36, 531-578.

[78] Puspitaningrum, D \& Atmini, S (2012), corporate governance mechanism and the level of Internet financial reporting: Evidence from Indonesian Companies, Procedia Economics and Finance, 2, 157-166. https://doi.org/10.1016/S2212-5671(12)00075-5.

[79] Trites, GD. (1999), The impact technology of financial and Business reporting, Canadian Institute of Chartered Accountants, CICC

[80] Turel, A (2010), The expectation Gap in Internet Financial Reporting: Evidence from an Emerging capital Market, Midde Eastern Finance and Economics, 8, 94-107

[81] Turrent, GCB \& Ariza, LR (2012), corporate information transparency on the Internet by listed companies in Spain (IBEX 35) and Mexico (IPYC). The international journal of digital accounting research, 12, 1-37. https://doi.org/10.4192/1577-8517-v12_1.

[82] Rogers, EM (1995), Diffusion of innovation, New York, the free press.

[83] Securities and Exchange Commission (2003), Mandated Electronic Filing and Website Posting for forums 3, 4 and 5, Final Rule: Release $\mathrm{N}^{\circ} 33-8230$, https://www.sec.gov/rules/final/33-8230.

[84] Verrcchia, RE (1983), Discretionary disclosure, Accounting and Economics, 5, 179-194.

[85] Watson, A, Shrives, P\& Marston, C (2002), Voluntary Disclosure of Accounting Ratios in the UK, British Accounting Review, 34, 289-313. https://doi.org/10.1006/bare.2002.0213.

[86] Watts, RL \& Zimmerman, JL (1978), Towards a positive theory of the determination of accounting standards, The Accounting Review, L III, 112-134.

[87] Xiao, JZ, Yang, H \& Chow, CW (2004), the determinants and Characteristics of voluntary Internet based disclosure by listed Chinese companies, Journal of accounting and Public Policy, 23, 191 225.https://doi.org/10.1016/j.jaccpubpol.2004.04.002. 